\title{
Only Attract Ants? The Versatility of Petiolar Extrafloral Nectaries in Passiflora
}

\author{
Poliana Cardoso-Gustavson ${ }^{1,2^{*}}$, Nathalia L. Andreazza ${ }^{1}$, Alexandra C. H. F. Sawaya ${ }^{3}$, \\ Marilia de Moraes Castro ${ }^{3}$ \\ ${ }^{1}$ Pós-Graduação em Biologia Vegetal, Instituto de Biologia, Universidade Estadual de Campinas, Campinas, Brazil; ${ }^{2}$ Núcleo de \\ Pesquisa em Anatomia Vegetal, Instituto de Botânica, São Paulo, Brazil; ${ }^{3}$ Departamento de Biologia Vegetal, Instituto de Biologia, \\ Universidade Estadual de Campinas, Campinas, Brazil. \\ Email: " cardoso.poliana@gmail.com
}

Received December $21^{\text {st }}, 2012$; revised January $21^{\text {st }}, 2013$; accepted January $28^{\text {th }}, 2013$

\begin{abstract}
Passiflora species presents a coevolutive relationship with Heliconiini butterflies, their primary herbivores. The Heliconiini caterpillars are able to detoxify toxic compounds produced by Passiflora, thus morphological defense strategies stand out over chemical innovations. In this framework, we highlight the presence of mimetic structures and extrafloral nectaries (EFN) as morphological strategies. Heliconian butterflies oviposit only on leaves that do not possess previous eggs, so the presence of egg mimics could prevent the oviposition. EFN are glands that offer nectar to territorial and aggressive ants, establishing mutualistic relationships. Here, we present a structural and chemical analysis of petiolar EFN and nectar from Passiflora alata and P. edulis in order to have insights about the implications of these features in deterring heliconian caterpillars. P. alata have one to four stipitate-crateriform EFN while P. edulis possess a pair of convex glands. Butterflies lay their eggs isolatedly or in up to three on leaves of both species. Our morphological results suggest that EFN from P. alata may act as egg mimics. Ontogenetic data suggest that the variation in the number of glands observed in this species is a serial homology, wherein the selection pressure for this variation is possibly the oviposition pattern. P. alata retain alkaloids, flavonoids and terpenoids inside nectariferous cells; sugars and flavonoids are found in the nectar of both species, while alkaloids are also detected in $P$. edulis. There is a selective retention/release of secondary metabolites from the EFN tissues to nectar. Knowing that these compounds can be dissuasive to some herbivores and inoffensive to others, we plotted this relationship in a consumer growth versus secondary metabolite concentration diagram. Our results suggest a more active role in the modulation of the gland defense from plants besides the establishment of a mutualistic relationship with ants, an important response in a coevolutive scenario.
\end{abstract}

Keywords: Passiflora alata Curtis; Passiflora edulis Sims; Egg Mimics; Anatomy; Secondary Metabolites

\section{Introduction}

Passiflora L. species presents a great vegetative structural complexity as a result of evolutionary advances developed from coevolutive relationships with their primary herbivores, the butterflies from Heliconiini tribe [1-3]. Caterpillars of Agraulis, Dione, Eueides and Heliconius species can easily defoliate the host plants and represent the major biotic challenge to survival of Passiflora in tropics $[1,2,4]$.

Changes in the behavior of the herbivores caused by morphological strategies of plants possess greater influence over the course of evolution of Heliconiini butterflies and Passiflora in detriment to the presence of defensive chemical compounds $[5,6]$. Considering the ability of Heliconius butterflies to detoxify compounds pro-

\footnotetext{
"Corresponding author.
}

duced by Passiflora species [7], the development of morphological strategies becomes essential to the maintenance of the fitness of these species.

Passiflora possess several defense strategies, highlighting the morphological innovations as mimics structures and extrafloral nectaries (EFN) as an evolutionary response to herbivorous caterpillars [3]. Egg mimics are structures derived from diverse plant tissues that present morphological features resembling butterflies eggs. These structures discourage butterflies ovipositions that possess solitary and aggressive caterpillars [8]. EFN are a biotic defense which glands present on several vegetative or reproductive organs-not related to pollination-offer nectar to territorial and aggressive ants, establishing mutualistic relationships [9]. Simple sugars are predominant in nectar composition, while other compounds as secondary metabolites occur in lower concentration [10,11], although 
this occurrence is best documented in nectar from floral nectaries [11-13].

Passiflora alata and P. edulis are species of high economical value. Both possess a distinct morphology of petiolar EFN. P. alata has one to four glands whose number varies in the same branch; these glands are about 1 $2 \mathrm{~mm}$ high and yellowish stipitate-crateriform shape (Figure 1(a)). P. edulis has a pair of EFN on the base of the leaf blade, $1.5 \mathrm{~mm}$ high, green on shaded plants (Figure 1(g)) and reddish on plants exposed to sunlight (Figures 1(e) and (f)).

We focused on structural and chemical aspects of petiolar EFN because the modulation of the qualitative aspects of the nectar produced and released from these glands can be a morphological strategy against heliconnian caterpillars within a coevolutive scenario. We also suggest a possible path that allows the plant to relate differently to herbivores and mutualistic invertebrates.

\section{Materials and Methods}

\subsection{Plant Material and Field Observations}

Vegetative branches of three individuals of Passiflora alata and $P$. edulis were collected from plants growing in Centro de Pesquisas Químicas, Biológicas e Agrícolas
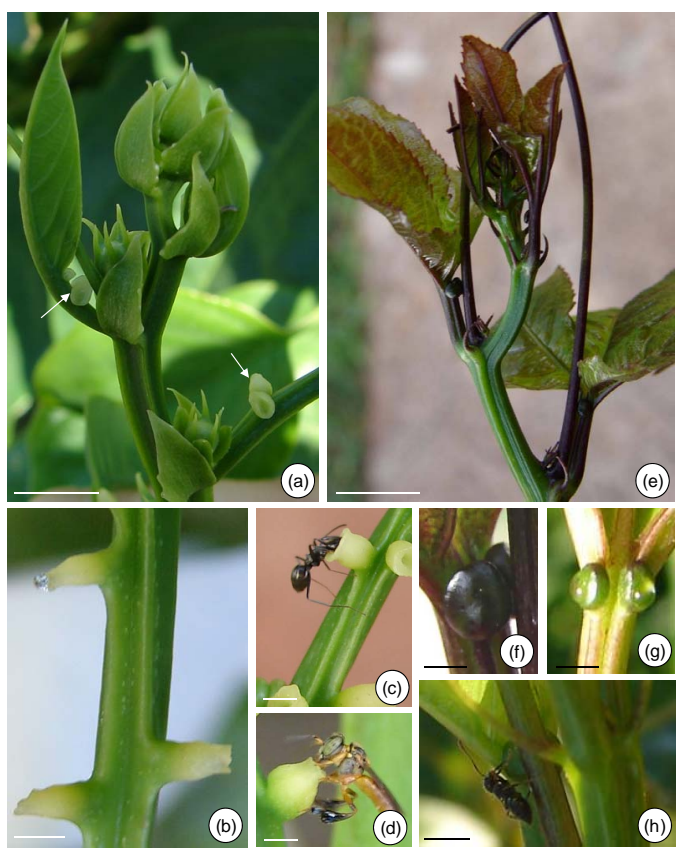

Figure 1. Field observations of Passiflora alata Curtis (a)-(d) and $P$. edulis Sims (e)-(g). (a) and (e) Vegetative shoot apex and subsequent visible nodes. (a) Asynchrony and variation in the number of glands on third and fourth petiole (arrows). (b) and (f)-(g) Profuse exudate on EFN at secretory phase. (f)-(g) A pair of synchronous EFN of plants exposed to shade (f) and sunlight (g) conditions. (c) and (h) Crematogaster ant collecting nectar. (d) Tetragonisca angustula worker bee robbing nectar. Bars: $2 \mathrm{~cm}$.
(CPQBA, Brazil). Voucher specimens were deposited in the Herbarium of Universidade Estadual de Campinas ( $P$. alata: UEC 145620; P. edulis: UEC 111509).

Morphological aspects of individuals exposed to shade and sunlight conditions were registered. Two plants of each species were observed over four consecutive days during the beginning of the morning (4 - $7 \mathrm{am})$ in the months of December to March (2008/2009). Nectar feeding visitors were collected, preserved in $70 \%$ ethanol and sent for identification.

The base of branches was isolated with Tanglefood grease to avoid the removal of the exudate by insects. In the subsequent morning, exudate was tested with Glicophita Plus (Bayer S. A.) [14] and collected for chemical analysis.

\subsection{Scanning Electron Microscopy (SEM)}

Petiolar EFN at different developmental stages were fixed in Karnovsky [15]. The material was washed, dehydrated in a graded ethanol series, critical point dried and coated with a thin layer of gold. Observations were carried out on a JEOL JSM 5000 LV 6350 scanning electron microscope at an accelerating voltage of $20 \mathrm{kV}$.

\subsection{Light Microscopy}

Petiolar EFN were fixed in FAA [16] for 24 hours and in Lillie's buffered neutral formalin [17] for 48 hours to better preserve hydro and lipophilic compounds, respectively. The material was isolated and dehydrated in a graded tertiary butanol series [16] and embedded in Paraplast. The serial sections were stained with Safranin and Astra blue [18], and Flemming's triple staining [16]. The sections were also examined under polarized light to verify the occurrence of starch grains, crystals and tracheary elements.

Histochemical tests were performed in both fresh and fixed material. Treatments and target compounds are summarized in Table 1. Standard control procedures were carried out according to the respective techniques.

\subsection{Chemical Characterization of Nectar}

The exudate from EFN of both species were collected with a microcapillary, clustered and stored in eppendorff tubes at $-10^{\circ} \mathrm{C}$. A $10 \mu \mathrm{l}$ aliquot of exudate was dissolved at a concentration of $50 \mu \mathrm{g} / \mathrm{ml}$ in water:methanol (7:3, v: v) containing $1 \%$ formic acid. These solutions were analysed by direct infusion with a syringe pump (Harvard Apparatus) at a flow rate of $10 \mu \mathrm{L} / \mathrm{min}$.

ESI-MS mass spectra were acquired in the positive ion mode using a hybrid high resolution Micromass Q-TOF mass spectrometer, under the following conditions: Capillary $+3000 \mathrm{~V}$, cone $+40 \mathrm{~V}$, dessolvation temperature $100^{\circ} \mathrm{C}$. 
Table 1. Results of the histochemical tests performed on EFN of Passiflora alata Curtis and P. edulis Sims.

\begin{tabular}{|c|c|c|c|}
\hline \multirow{3}{*}{ Treatment } & \multirow{3}{*}{ Target compounds } & \multicolumn{2}{|c|}{ Petiolar extrafloral nectaries (EFN) } \\
\hline & & P. alata & P. edulis \\
\hline & & Idioblasts and nectariferous cells & Nectariferous cells \\
\hline PAS reaction [19] & polysaccharides & $\stackrel{+}{\text { Figure 5(a) }}$ & $\begin{array}{c}+ \\
\text { Figure 6(e) }\end{array}$ \\
\hline Sudan black B [20] & lipids & $\stackrel{+}{\text { Figure 5(b) }}$ & - \\
\hline Nadi reagent $[21]$ & terpenoids & $\stackrel{+}{\text { Figure 5(d) }}$ & - \\
\hline Formalin-ferrous sulphate fixative [16] & phenolic compounds & $\stackrel{+}{\text { Figure 5(e) }}$ & - \\
\hline Naturstoff reagent ${ }^{*}[22]$ & flavonoids & $\stackrel{+}{\text { Figure 5(f) }}$ & - \\
\hline Dragendorff reagent [23] & alkaloids & $\begin{array}{c}+ \\
\text { Figure 5(g) }\end{array}$ & - \\
\hline
\end{tabular}

Notes: ${ }^{*}$ excitation at $350-390 \mathrm{~nm} ;+$, positive reaction; -, negative reaction.

\section{Results}

\subsection{Macromorphological Data and Field Observations}

There is an asynchrony concerning the development and release of nectar from petiolar EFN of P. alata, where it all starts on glands close to the stem (basal glands, Figure 1(a)). During secretory phase, nectar accumulates on the crateriform region of the nectary and is exhibited in the apex of the gland (upper gland, Figure 1(b)).

Anthocyanins are visualized on young organs of $P$. edulis exposed to sunlight (Figure 1(e)). In this species, EFN presents a synchronous development and the release of nectar can be seen over the gland surface (Figures 1(f) and $(\mathbf{g})$ ).

The secretory phase of petiolar EFN is recognized since the second visible node in both species. Profuse exudate is registered only in plants whose base of branches was isolated with Tanglefoot grease (Figures 1(b), (f) and (g)). Crematogaster ants are observed collecting the nectar from both species (Figures 1(c) and (h)) and eventually can injure the secretory epidermis of EFN of P. edulis. Worker bees of Tetragonisca angustula also collect the nectar from P. alata (Figure 1(d)).

\subsection{Micromorphological, Ontogenetic and Histochemical Data}

The meristematic phase of EFN is identified by the appearance of protuberances on the base of leaf primordium (Figures 2(a-c)). The presecretory phase of $P$. alata is characterized by the stretching of the peripheral portion until it acquires a stipitate-crateriform shape (Figures 3(a) and (b)). In P. edulis, the protuberances increase in volume until become flat in shape (Figure 2(d)), an indicative of the beginning of presecretory phase; the
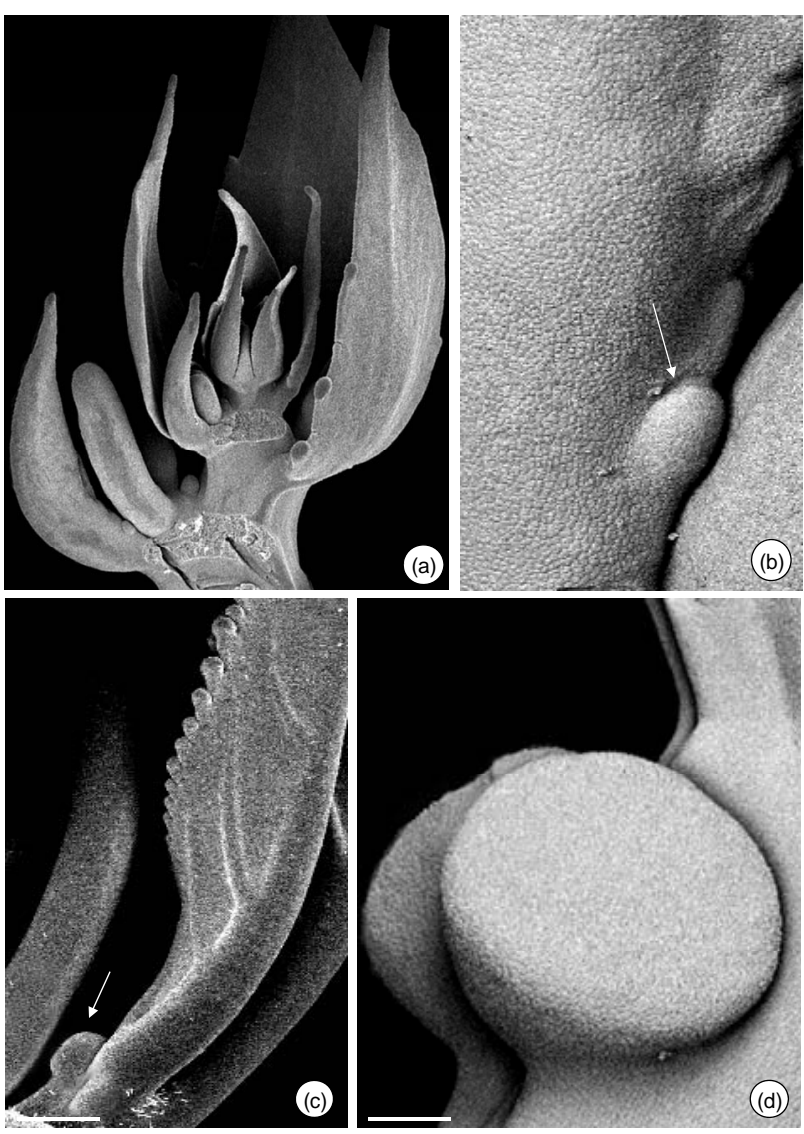

Figure 2. Petiolar EFN development of Passiflora alata Curtis (a) and (b) and P. edulis Sims (c) and (d). (a) Vegetative shoot apex. (b) and (c) EFN at meristematic phase (arrows). (d) EFN at presecretory phase; note the flattened shape. Bars: $1 \mathrm{~mm}$ (a) and (c), $500 \mu \mathrm{m}$ (b) and (d).

morphology of the EFN at the end of this phase is a convex shape, as a result of the increase in volume of the gland. 

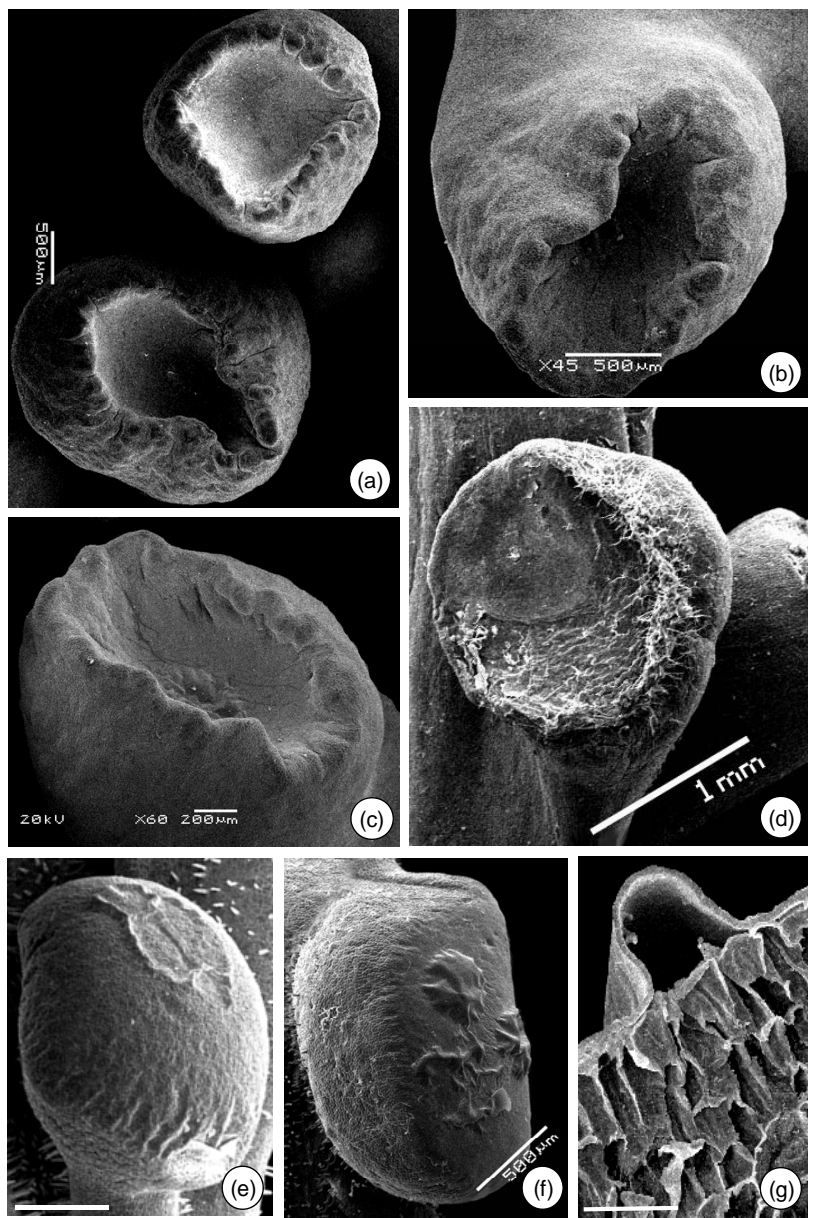

Figure 3. Petiolar EFN micromorphology of Passiflora alata Curtis (a)-(d) and P. edulis (e)-(g). (a) Asynchrony of EFN: upper gland at the presecretory and lower gland at the secretory phase. (b) and (e) Stipitate-crateriform (b) and convex (e) shape of EFN at the secretory phase. (c) and (f) Note the detached cuticle of EFN at the secretory phase. (e) EFN at the post-secretory phase: note fungal hyphae. (g) Subcuticular space where nectar is confined. Bars: $500 \mu \mathrm{m}(\mathrm{e})$, $300 \mu \mathrm{m}$ (g).

The asynchrony in the development of EFN of $P$. alata is shown in Figures 3(a) and 4(a). Only the central region of EFN has nectariferous cells (Figure 4(b)); the peripheral region consists of ordinary epidermal cells (Figure 4(f)). Note in Figures 4(b) and 6(a) that pre-nectar can be seen inside nectariferous cells fixed in FAA. There is a differential preservation of cell content according to the fixative used.

The secretory phase is recognized by cuticle detachment in the central region of the petiolar EFN (Figures 3(c) and (e)-(g)). Initially, small elevations are observed and then they protrude, rising in the convex region (Figures 3(e)-(g)). The subcuticular space is shown in the transversal section of EFN (Figures 3(g), 4(c) and 6(c)). The anatomical features of EFN on secretory phase are presented ahead.
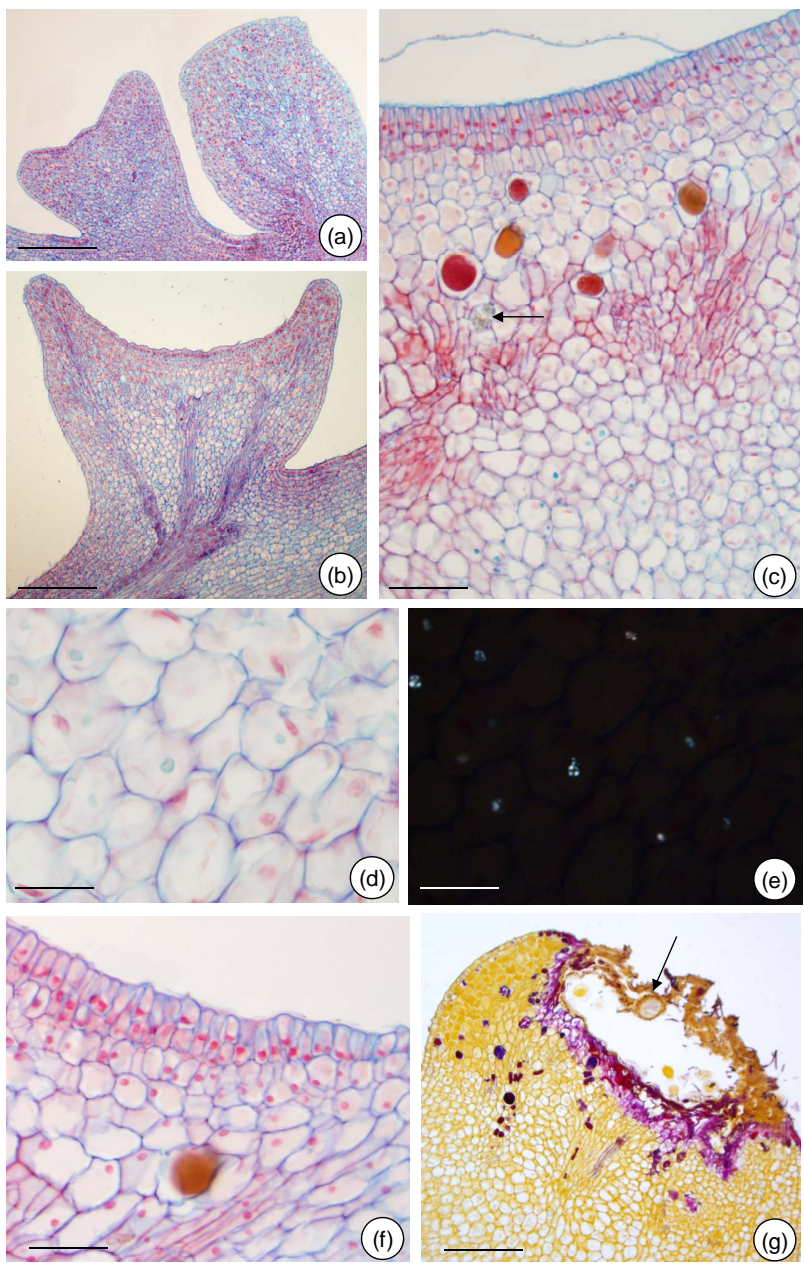

Figure 4. Petiolar EFN structure of Passiflora alata Curtis. (a) Upper gland at the meristematic phase and lower gland at the presecretory phase; (b) Nectariferous cells with dense content (pre-nectar); (c) Detached cuticle and idioblasts scattered through nectariferous parenchyma; note the crystal (arrow); (d) and (e) Few starch grains in subnectariferous parenchyma under polarized light (e). (f) Non-secretory cells at EFN edges. (g) EFN at post-secretory phase: note fungal hyphae (arrow). Bars: $150 \mu \mathrm{m}$ (a), $75 \mu \mathrm{m}$ (b), $50 \mu \mathrm{m}$ (c), 25 $\mu \mathrm{m}$ (d) and (e), $30 \mu \mathrm{m}$ (f) and (g).

Nectariferous epidermis the multiple epidermis is covered with a thin cuticle (Figures 5(b) and (c), 6(b, e and f)) and cuticular flanges extend up to the inner periclinal wall of the first cell layer (Figures 5(c), 6(b and f)). The release of the nectar through nectariferous epidermis promotes the cuticle detachment. Nectar is confined to a subcuticular space, situated between the cuticle and the outer periclinal wall of epidermal cells (Figures 5(c) and 6(e)). Cuticle disruption was observed only after ants collect nectar from EFN of $P$. edulis.

Nectariferous parenchyma and subnectariferous parenchyma-are distinct in both species. Both tissues are separated from each other by vascular terminations (Figures 4(c) and 6(c)). EFN of $P$. alata possess secretory 

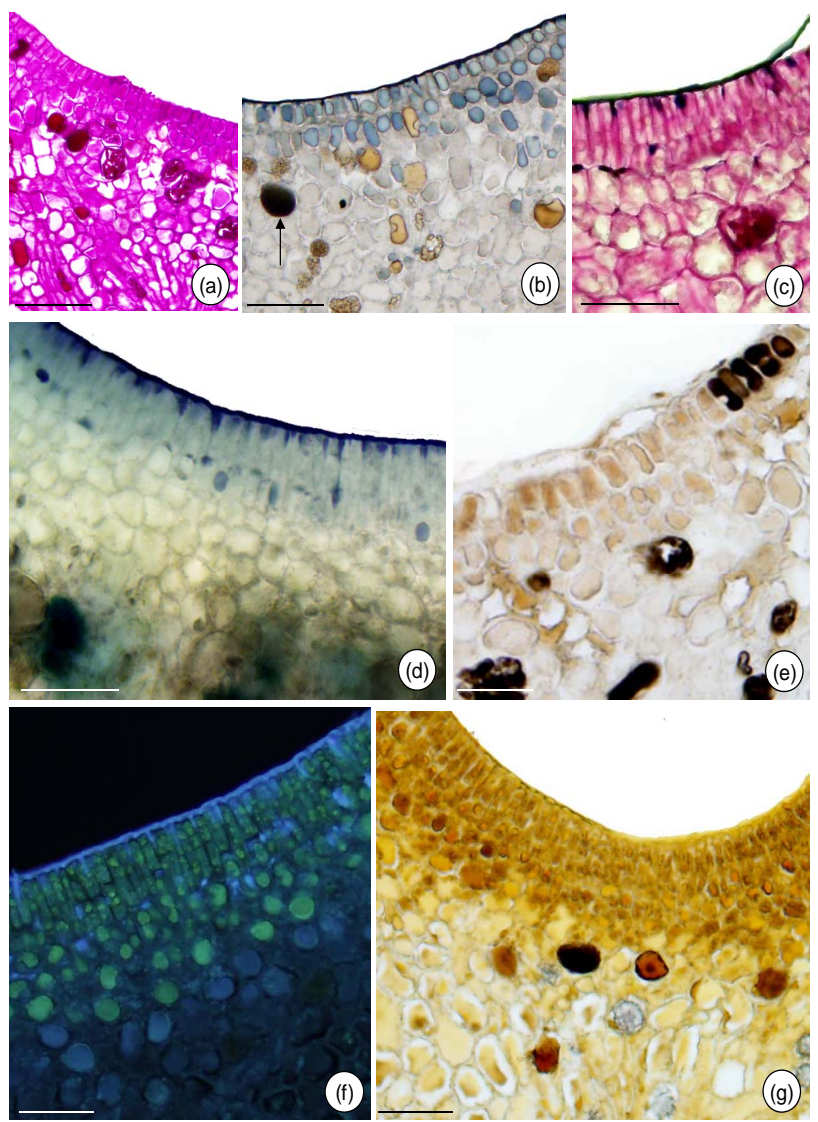

Figure 5. In situ localization of some metabolites in petiolar EFN of Passiflora alata Curtis. (a) PAS reaction; (b) Sudan black B; (c) PAS reaction plus Sudan black B; (d) Nadi reagent; (e) Formalin-ferrous sulphate fixative; (f) Naturstoff reagent under UV light; (g) Dragendorff reagent. Bars: $75 \mu \mathrm{m}$ (a) and (c), $30 \mu \mathrm{m}$ (b), (d), (e)-(g).

idioblasts scattered through the nectariferous parenchyma (Figure 4(c)). The subnectariferous parenchyma presents few starch grains (Figures 4(d) and (e)) and crystals close to the vascular bundles (Figure 5(c)). Secretory idioblasts and starch grains are not visualized on EFN of $P$. edulis (Figures 6(a)-(f)).

Vascular tissue - the main trace comes from the petiole and it branches at the base of the nectary (Figure 4(b)). Vascular terminations consist of phloem only, and are embedded in the nectariferous parenchyma (Figures 4(c) and 6(c)).

The post-secretory phase is characterized by the establishment of fungal hyphae over the EFN secretory region in both species and by flattening the EFN edges of $P$. alata (Figures 3(d) and 4(g)).

The histochemical results are summarized in Table 1. The tests indicate the presence of terpenoids, phenolic compounds and alkaloids inside idioblasts and some nectariferous cells of P. alata (Figures 5(d) and (g)). Fresh section of $P$. edulis EFN shows anthocyanin restricted to non-secretory epidermis (Figure 6(d).
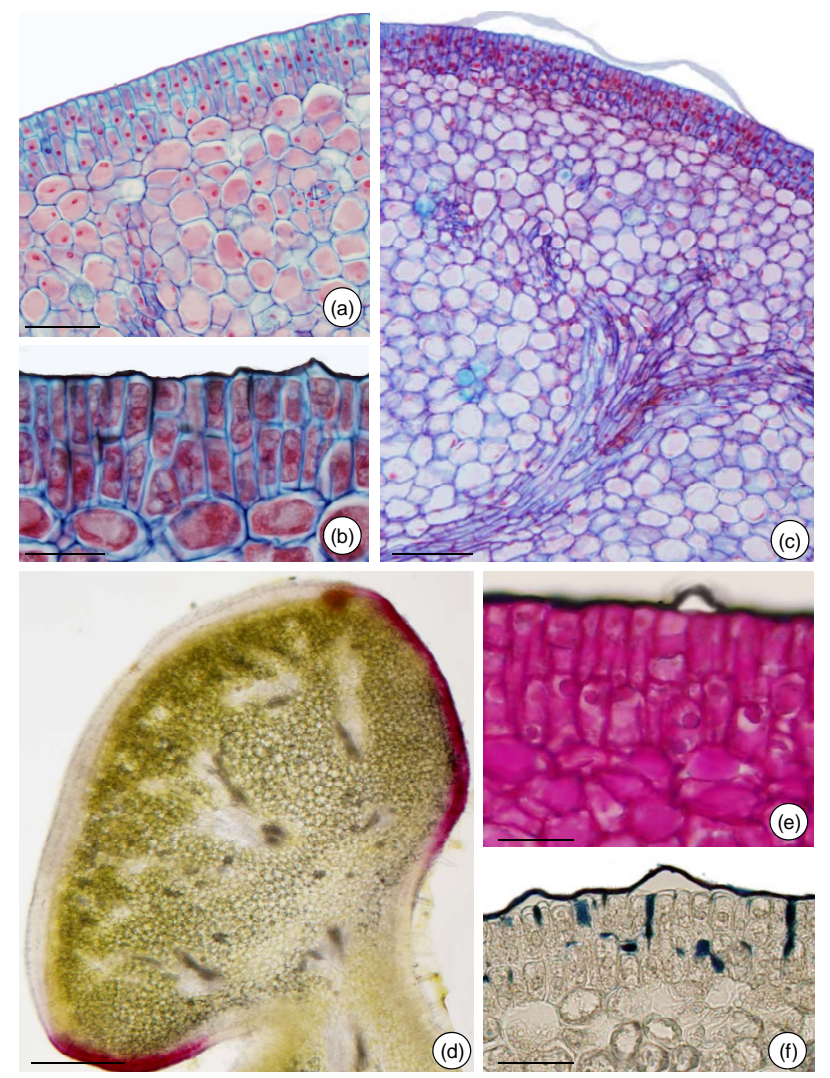

Figure 6. Structure and in situ localization of some metabolites in petiolarEFN of Passiflora edulis Sims. (a) and (b) Multiple nectariferous epidermis and nectariferous parenchyma: note dense cell content (pre-nectar). (b), (c), (e) and (f) Cuticle detached and intact. (b) and (f) Cuticular flanges evidenced by Sudan black (b) and (c) Nectariferous parenchyma delimitated by vascular terminations. (d) Anthocyanins seen in fresh section. (e) PAS reaction plus Sudan black B. (f) Sudan black B. Bars: $30 \mu \mathrm{m}$ (a), $75 \mu \mathrm{m}$ (b), (e) and (f), $25 \mu \mathrm{m}$ (c), $150 \mu \mathrm{m}$ (d).

\subsection{Chemical Analysis of Nectar}

Glucose, fructose and sucrose were detected in nectar of both species (Figures 7 and 8). The hexoses (mass 180 Da) were detected mainly as their sodium $(\mathrm{m} / \mathrm{z} 203)$ and potassium ( $\mathrm{m} / \mathrm{z} 219)$ adducts. Glucose (mass $341 \mathrm{Da})$ was observed as its protonated $(\mathrm{m} / \mathrm{z} 342)$ form as well as sodium $(\mathrm{m} / \mathrm{z} 365)$ and potassium $(\mathrm{m} / \mathrm{z} 381)$ adducts.

Among the secondary metabolites, apigenin (flavonoid) was detected in both species $(\mathrm{m} / \mathrm{z} 271)$ Harmine, an alkaloid, was found only in nectar of $P$. edulis (Figure 9) as its sodium adduct $(\mathrm{m} / \mathrm{z} 251)$.We searched for alkaloids and flavonoids commonly found in these species [24].

\section{Discussion}

\subsection{Morphological and Ecological Considerations}

The visual selection conditioned many diversifications of leaf morphology on Passiflora and other tropical plants 


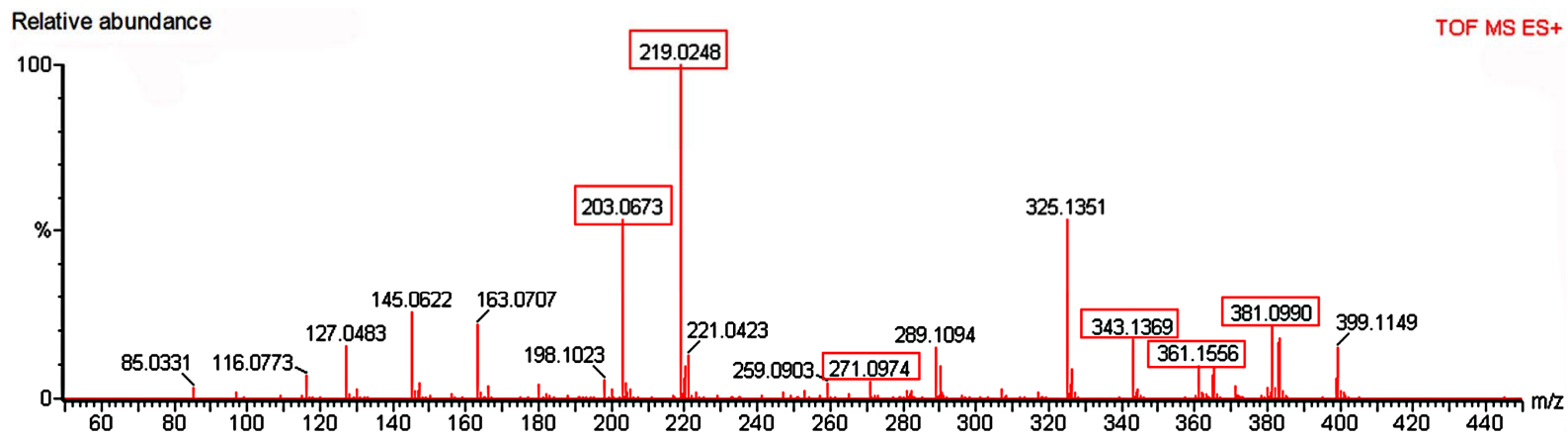

Figure 7. Mass spectrum of nectar from petiolar EFN of $P$. alata Curtis. Red boxes refer to the profile of mass corresponding to glucose, fructose ( $\mathrm{m} / \mathrm{z} 203$ and 219), sucrose $(\mathrm{m} / \mathrm{z} 343,361$ and 381) and apigenin $(\mathrm{m} / \mathrm{z} 271)$.

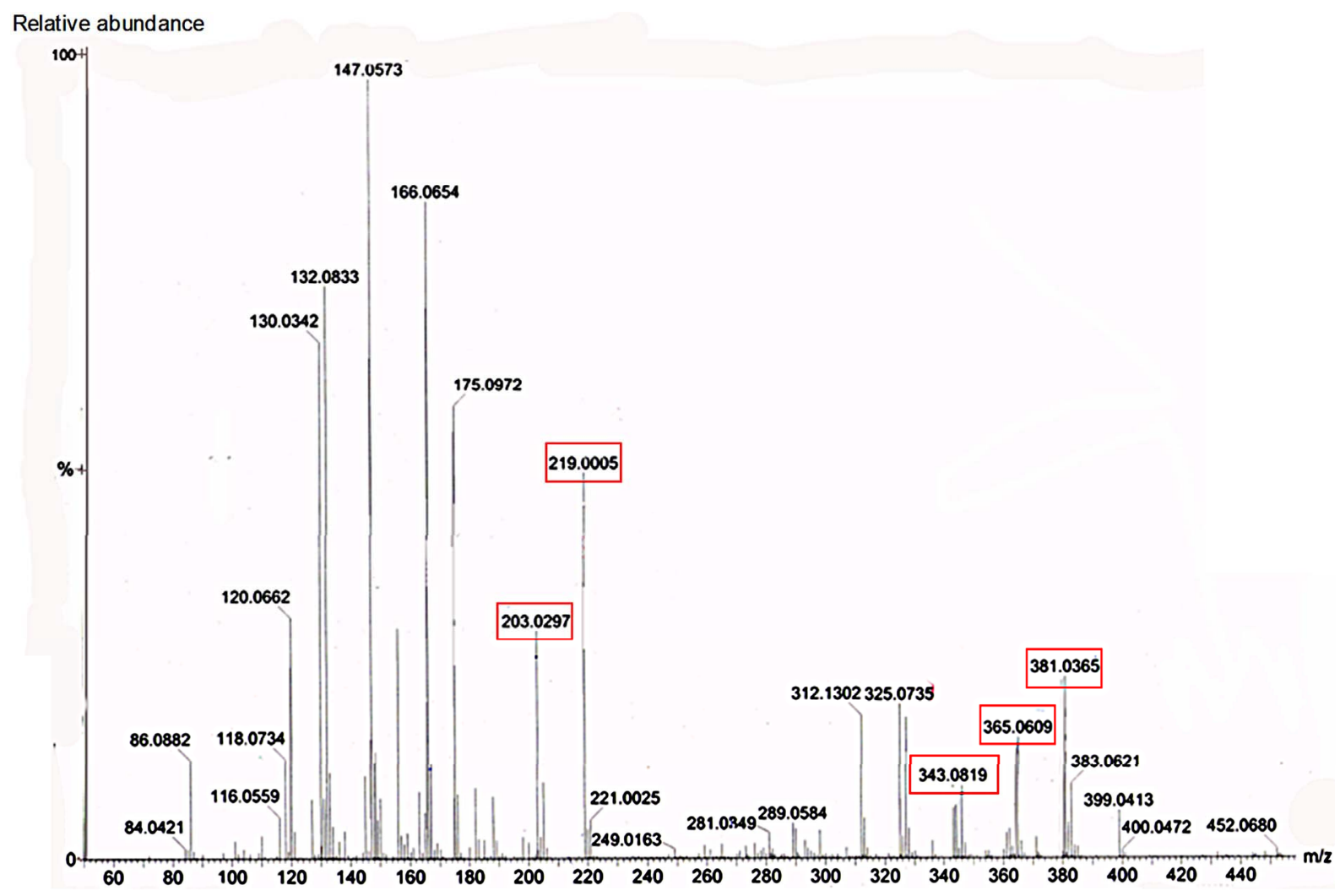

Figure 8. Mass spectrum of nectar from petiolar EFN of $P$. edulis Sims. Red boxes refer to the profile of mass corresponding to glucose, fructose ( $m / z 203$ and 219) and sucrose $(m / z 343,365$ and 381).

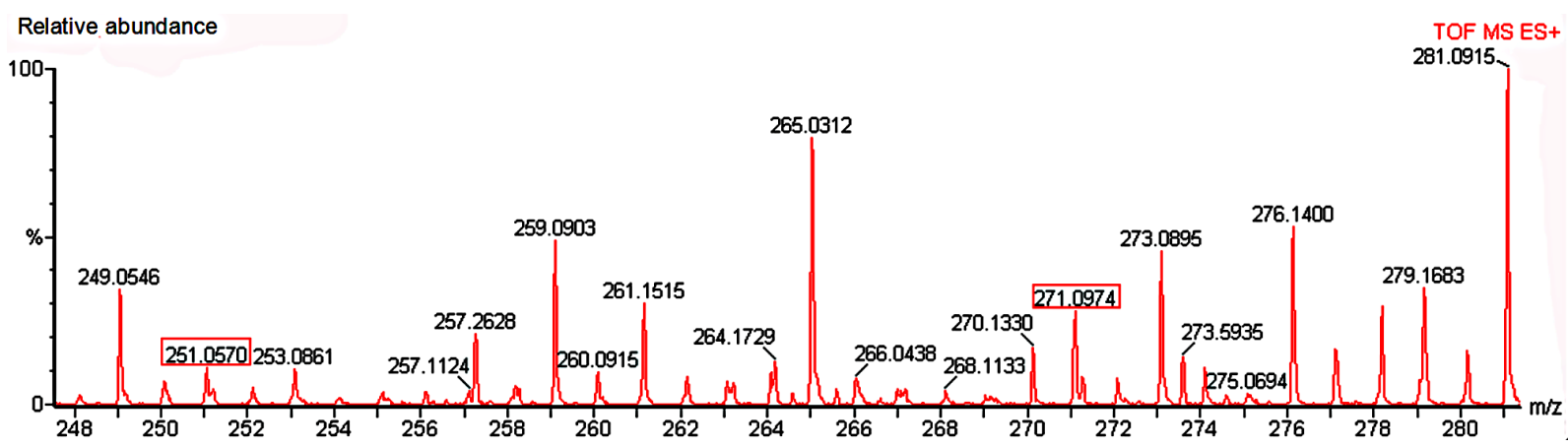

Figure 9. Mass spectrum of nectar from petiolar EFN of $P$. edulis Sims. Red boxes refer to the profile of mass corresponding to hamine $(\mathrm{m} / \mathrm{z} 251)$ and apigenin $(\mathrm{m} / \mathrm{z} 271)$. 
taxa [8]. Behavioral experiments show that Heliconius butterflies present color vision as a possible answer to selection of the discriminative ability of oviposition sites by females [26-29], although the chemical stimuli are not excluded [6].

The sensibility spectra of color vision of Heliconiinae butterflies is 300 to $700 \mathrm{~nm}$, where the peak of maximum sensibility is about $450-560 \mathrm{~nm}$, corresponding to blue and yellow colors, respectively [28]. Agraulis vanillae, Eueides isabella and Heliconius erato stand out among heliconian species that consume $P$. alata leaves [30]. The description of their eggs in the surveyed literature [31] shows morphological similarities with the petiolar EFN of $P$. alata. Butterflies of these species oviposit only on young organs of the plant that do not possess previous eggs $[5,31]$. The presence of egg mimics prevents the oviposition of heliconian females, avoiding the feeding of plants by caterpillars. These species lay their eggs isolatedly or in groups of up to three on E. isabella. The selective pressure from those heliconian species could explain the variation among the number of EFN that exists in the same individual of $P$. alata, simulating distinct ovipositions on each petiole.

Plants of $P$. edulis exposed to sunlight present anthocyanins on the epidermis of young organs and are less consumed in comparison to shaded individuals. Anthocyanins stand out as constitutive defenses that act over herbivorous and are modulated by plants [32]. The most accepted hypothesis for anthocyanins as legitimate antiherbivory defenses refers to the aposematic color observed in plants that possess this pigment, inhibiting herbivores that do not recognize the red color [33]. Heliconius species do not show sensibility to the wavelengths related to this color [25] and cannot recognize the young organs preferential to oviposition, which could justify the lower consumption of plants under sunlight. However, parasitism and predation of this species could increase the incidence of herbivory: those two events can overwhelm lianas present in sunlight areas and explain why some butterfly species are not common in those places $[5,34]$.

Sugars present in the exudate are the main source of this substance to mutual Crematogaster ants [35]. The observation of profuse nectar only after the isolation of branches with innocuous grease shows that the exudate is constantly collected. The asynchrony of EFN from $P$. alata can provide nectar for a long period, while the synchrony of $P$. edulis may offer a higher volume of this source. The test with Glicophita Plus indicated the presence of glucose in the exudate, ensuring that those glands are EFN. According to MS analysis, the nectar contains glucose, fructose and sucrose. These mono and disaccharides seem to be important food sources to ants [36].
Besides ants, other insects as bees and wasps can also collect nectar from EFN [37-39]. This is the first register of Tetragonisca angustula collecting nectar from an EFN. These insects do not present an aggressive behavior. In this context, they are analogous to robber insects, in the same sense used for flower visitants that do not pollinate.

The secretory phase of petiolar EFN occurs on young organs of both species. Feeding preference experiments show that Heliconius larvae select young leaves of Passiflora [40]. The presence of glands at the secretory phase limited to young portions of the plant - as already observed in other species of Passiflora [41] — can be related to the preference of heliconian females to lay eggs on young organs of plants [6].

\subsection{Structural Aspects}

The ontogenetic development of EFN from P. alata and $P$. edulis is consistent with other Passifloraceae species: the glands arise from the activity of the protoderm, procambium and ground meristem [41,42]. It also occurs with foliar EFN from Turneraceae species-Passifloraceae sensu lato [43] — and these glands are considered homologous structures $[39,41,42]$. The variation in the number of petiolar EFN, as found on $P$. alata and $P$. amethystina [41], suggests the occurrence of serial homology. The selective pressure responsible for this variation can be related to the coevolution with heliconian.

The release of nectar through cuticle ruptures was observed on species that do not present the expansion of the EFN non-secretory region [42]. However, the rupture founded in some EFN of P. edulis was associated with ant aggressive behavior during nectar collection. Although we found nectar accumulation in the subcuticular space of $P$. alata, there was no observation of cuticle rupture. Even though there is a report of the inexistence of pores on the cuticle of the Passiflora species [42], we strongly suggest more accurate studies about cuticle structure during the secretory process.

\subsection{Chemical and Functional Aspects}

The crateriform morphology of EFN from P. alata can provide a microenvironment to confine terpenoids synthesized by the idioblasts, analogously to the corona in the flowers of Passiflora [44]. Terpenoids are the major volatile compounds issued by plants as an answer to herbivory, signalling to carnivorous arthropods either to prey or to parasitize herbivorous [45].

According to histochemical tests and the analysis on mass spectrometry, secondary metabolites are retained inside secretory cells (idioblasts and nectariferous cells) of the EFN from P. alata. A possible function of this retention would be the decrease in herbivory of these glands.

Alkaloids and flavonoids do not accumulate in the 
petiolar EFN from $P$. edulis, but are present in trace amount in nectar, suggesting that the concentrations of these compounds both in nectar and inside secretory cells possess a pleiotropic effect on the phloem [46]. The presence of secondary metabolites in nectar can be related to the attraction of specific consumers, since the deterrent or toxic nectar to some collector may not affect others [47]. Alkaloids, flavonoids and terpenoids are antifungical [48-50]. These metabolites can inhibit fungi proliferation, since hyphae are only found on the nonsecretory region of EFN of $P$. edulis and over petiolar EFN of both species at post-secretory phase.

Although histochemical tests and analysis of the nectar on MS provide qualitative results, it is possible to establish a relationship between the relative concentrations of secondary metabolites inside the plant and released by them in the nectar through the sensibility of both techniques. The MS sensitivity is femtogram-order, allowing the detection of trace compounds, as those present in the nectar. Histochemical tests present a lower sensitivity of microgram-order, detecting compounds in a higher concentration. Therefore, alkaloids and flavonoids are more concentrated inside the idioblasts than in the nectar of $P$. alata. The relationship between the concentration of secondary metabolites inside and outside the plant and the commitment of the development of herbivores and/or nectar collectors can be plotted on a growth versus concentration diagram, as shown in Figure 10.

The secondary metabolites present in higher concentration in the EFN of $P$. alata show deterrent function against herbivores. Those who are not able to detoxify these compounds undertake their development as these substances are accumulated in their organism. The low concentration of alkaloids and flavonoids in nectar is insufficient to affect the metabolism of collectors that establish a mutualistic relationship with $P$. alata and $P$. edulis. The analysis of the diagram suggests that the

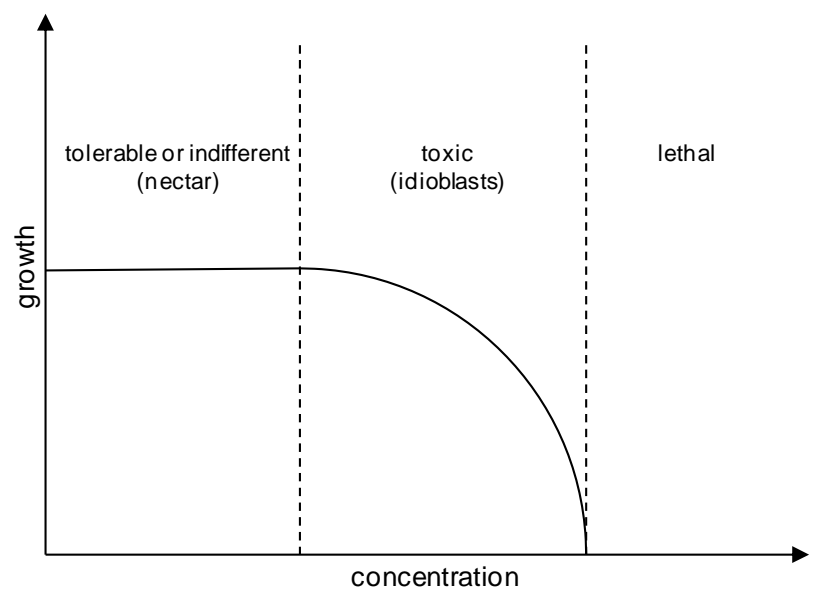

Figure 10. Diagram showing insect growth versus secondary metabolites concentration. modulation of the concentration of secondary metabolites allows the plant to relate differently to herbivores and mutualistic consumers, highlighting the importance of secretory tissues (idioblasts and nectariferous cells) in this process.

\section{Acknowledgements}

We thank to Prof. Dr. Carlos Roberto Brandão (Museu de Zoologia, Universidade de São Paulo) and Prof. Dr. Marlies Sazima (Departamento de Biologia Vegetal, Universidade Estadual de Campinas) for the identification of ants and bees, respectively. The first author was supported by Conselho Nacional de Desenvolvimento Científico e Tecnológico (CNPq 131813/2008-0).

\section{REFERENCES}

[1] W. W. Benson, K. S. Brown and L. E. Gilbert, "Coevolution of Plants and Herbivorous: Passion Flowers Butterflies," Evolution, Vol. 29, No. 4, 1975, pp. 659-680. doi: $10.2307 / 2407076$

[2] K. S. Brown, "The Biology of Heliconius and Related Genera," Annual Review of Entomology, Vol. 26, 1981, pp. 427-456. doi:10.1146/annurev.en.26.010181.002235

[3] K. C. Spencer, "Chemical Mediation of Coevolution in the Passiflora-Heliconius Interaction," In: K. C. Spencer, Ed., Chemical Mediation of Coevolution, Academic Press Inc., San Diego, 1988, pp. 168-175.

[4] L. E. Gilbert and J. T. Smiley, "Determinants of Local Diversity in Phytophagous Insects," In: L. A. Mound and N. Walloff, Eds., Diversity of Insect Faunas, Blackwell Scientific, London, 1978, pp. 89-104.

[5] W. W. Benson, "Resource Partitioning in Passion Vine Butterflies," Evolution, Vol. 32, No. 3, 1978, pp. 493-518. doi: $10.2307 / 2407717$

[6] K. S. Williams and L. E. Gilbert, "Insects as Selective Agents on Plant Vegetative Morphology: Egg Mimicry Reduces Egg Laying by Butterflies," Science, Vol. 212, No. 4493, 1981, pp. 467-469.

doi:10.1126/science.212.4493.467

[7] J. R. Trigo, "The Chemistry of Antipredator Defense by Secondary Compounds in Neotropical Lepidoptera: Facts, Perspectives and Caveats," Journal of the Brazilian Chemical Society, Vol. 11, No. 6, 2000, pp. 551-561. doi:10.1590/S0103-50532000000600002

[8] L. E. Gilbert, "Butterfly-Plant Coevolution: Has Passiflora adenopoda Won the Selectional Race with Heliconiine Butterflies?" Science, Vol. 172, No. 3983, 1971, pp. 585-586. doi:10.1126/science.172.3983.585

[9] J. F. Addicott, "Mutualistic Interactions in Population and Community Processes," In: P. W. Price, C. N. Slobodchikoff and P. S. Gaud, Eds., A New Ecology: Novel Approaches to Interactive Systems, John Wiley, New York, 1984, pp. 437-451.

[10] A. Fahn, "Structure and Function of Secretory Cells," Advances in Botanical Research, Vol. 31, 2000, pp. 37-75. 
doi:10.1016/S0065-2296(00)31006-0

[11] S. W. Nicolson, M. Nepi and E. Pacini, "Nectaries and Nectar," Springer-Verlag, The Netherlands, 2007. doi:10.1007/978-1-4020-5937-7

[12] L. S. Adler and R. E. Irwin, "Ecological Costs and Benefits of Defenses in Nectar," Ecology, Vol. 86, No. 11, 2005, pp. 2968-2978. doi:10.1890/05-0118

[13] I. G. Varassin, J. R. Trigo and M. Sazima, "The Role of Nectar Production, Flower Pigments and Odour in the Pollination of Four Species of Passiflora (Passifloraceae) in South Eastern Brazil," Botanical Journal of the Linnean Society, Vol. 136, No. 2, 2001, pp. 139-152. doi:10.1111/j.1095-8339.2001.tb00563.x

[14] A. C. A. Aguiar-Dias, L. Yamamoto and M. M. Castro, "Stipular Extranuptial Nectaries New to Polygala: Morphology and Ontogeny," Botanical Journal of the Linnean Society, Vol. 166, No. 1, 2011, pp. 40-50. doi:10.1111/j.1095-8339.2011.01123.x

[15] J. E. Kraus and M. Arduin, "Manual básico de métodos em morfologia vegetal," EDUR, Seropédica, 1997.

[16] D. A. Johansen, "Plant Microtechnique," McGraw-Hill Books, New York, 1940.

[17] R. D. Lillie, "Histopathologic Technic and Practical Histochemistry," McGraw Hill, New York, 1965.

[18] G. Gerlach, "Botanische Mikrotechnik," Georg Thieme Verlag, Stuttgard, 1975.

[19] J. F. A. Mc Manus, "Histological and Histochemical Uses of Periodic Acid," Stain Technology, Vol. 23, No. 3, 1948, pp. 99-108.

[20] A. G. E. Pearse, "Histochemistry: Theoretical and Applied," Churchill Livingstone, Edinburgh, 1985.

[21] R. David and J. P. Carde, "Coloration Différentielle Dês Inclusions Lipidique et Terpeniques dês Pseudophylles du pin Maritime au Moyen du Reactif Nadi," Comptes Rendus de I'Academie des Sciences Paris, Vol. 258, 1964, pp. 1338-1340.

[22] M. Tattini, E. Gravano, P. Pinelli, N. Milinacci and A. Romani, "Flavonoids Accumulate in Leaves and Glandular Trichomes of Phillyrea latifolia Exposed to Excess Solar Radiation," New Phytologist, Vol. 148, No. 1, 2000, pp. 69-77. doi:10.1046/j.1469-8137.2000.00743.x

[23] L. R. Yoder and P. G. Mahlberg, "Reactions of Alkaloid and Histochemical Indicators in Laticifers and Specialized Parenchyma Cells of Catharanthus roseus (Apocynaceae)," American Journal of Botany, Vol. 63, No. 9, 1976, pp. 1167-1173. doi:10.2307/2441734

[24] K. Dhawan, S. Kumar and A. Sharma, "Passiflora: A Review Update," Journal of Ethnopharmacology, Vol. 94, No. 1, 2004, pp. 1-23. doi:10.1016/j.jep.2004.02.023

[25] J. Crane, "Imaginal Behaviour of a Trinidad Butterfly, Heliconius erato hydara Hewitson, with Special Reference to the Social Use of Color," Zoologica, Vol. 40, 1955, pp. 167-196.

[26] J. Crane, "Imaginal Behavior in Butterflies of the Family Heliconiidae: Changing Social Patterns and Irrelevant Actions," Zoologica, Vol. 42, 1957, pp. 135-145.

[27] C. A. Swihart, "Colour Discrimination by the Butterfly,
Heliconius charitonius Linn," Animal Behavior, Vol. 19, No. 1, 1971, pp. 156-164. doi:10.1016/S0003-3472(71)80151-3

[28] G. Struwe, "Spectral Sensitivity of Single Photoreceptors in the Compound Eye of a Tropical Butterfly (Heliconius numata)," Journal of Comparative Physiology, Vol. 79, No. 2, 1972, pp. 196-201.

[29] A. Kelber, A. Balkenius and E. J. Warrant, "Colour Vision in Diurnal and Nocturnal Hawkmoths," Integrative and Comparative Biology, Vol. 43, No. 4, 2003, pp. 571579. doi:10.1093/icb/43.4.571

[30] K. C. Spencer, "Chemical Mediation of Coevolution in the Passiflora-Heliconius Interaction,” In: K. C. Spencer, Ed., Chemical Mediation of Coevolution, San Diego, Academic Press Inc., 1988, pp.168-175.

[31] R. Dell'Erba, L. A. Kaminski and G. R. P. Moreira, "O estágio de ovo dos Heliconiini (Lepidoptera: Nymphalidae) do Rio Grande do Sul, Brasil," Iheringia Série Zoologia, Vol. 95, No. 1, 2005, pp. 29-46. doi:10.1590/S0073-47212005000100006

[32] S. Koptur, "Extrafloral Nectary-Mediated Interactions between Insects and Plants," In: E. Bernays, Ed., Insect Plant Interactions, CRC Press, Boca Raton, 1992, pp. 81129.

[33] P. Karageorgou, C. Buschmann and Y. Manetas, "Red Leaf Color as a Warning Signal against Insect Herbivory: Hones or Mimetic?" Flora, Vol. 203, No. 8, 2008, pp. 648-652. doi:10.1016/j.flora.2007.10.006

[34] B. L. Bentley, "Plants Bearing Extrafloral Nectaries and the Associated Ant Community Interhabitat Differences in the Reduction of Herbivory Damage," Ecology, Vol. 57, No. 4, 1976, pp. 815-820. doi:10.2307/1936195

[35] J. Lanza, "Ant Preferences for Passiflora Nectar Mimics That Contain Amino Acids," Biotropica, Vol. 20, No. 4, 1988, pp. 341-344. doi:10.2307/2388328

[36] M. Heil, J. Pattke and W. Boland, "Postsecretory Hydrolysis of Nectar Sucrose and Specialization in Ant/Plant Mutualism," Science, Vol. 308, No. 5721, 2005, pp. 560563. doi:10.1126/science. 1107536

[37] D. A. Baker, J. L. Hall and J. R. Thorpe, "A study of the Extrafloral Nectaries of Ricinus communis," New Phytologist, Vol. 81, No. 1, 1978, pp. 129-137. doi:10.1111/j.1469-8137.1978.tb01612.x

[38] D. J. O'Dowd, "Foliar Nectar Production and Ant Activity on a Neotropical Tree, Ochroma pyramidale," Oecologia, Vol. 43, No. 2, 1979, pp. 233-248. doi: $10.1007 / \mathrm{BF} 00344773$

[39] T. S. Elias, "Extrafloral Nectaries: Their Structure and Distribution," In: B. Bentley and T. Elias, Eds., The Biology of Nectaries, Columbia University Press, New York, 1983, pp. 174-182.

[40] R. F. Denno and M. A. Donnelly, "Patterns of Herbivory on Passiflora Leaf Tissues and Species by Generalized and Specialized Feeding Insects," Ecological Entomology, Vol. 6, No. 1, 1981, pp. 11-16. doi:10.1111/j.1365-2311.1981.tb00967.x

[41] D. I. Rocha, L. C. Silva, V. M. M. Valente, D. M. T. Francino and R. M. S. A. Meira, "Morphoanatomy and 
Development of Leaf Secretory Structures in Passiflora amethystine Mikan (Passifloraceae)," Australian Journal of Botany, Vol. 57, No. 7, 2009, pp. 619-626. doi:10.1071/BT09158

[42] L. T. Durkee, "The Floral and Extra-Floral Nectaries of Passiflora. II. The Extra-Floral Nectary," American Journal of Botany, Vol. 69, No. 9, 1982, pp. 1420-1428. doi: $10.2307 / 2443103$

[43] APG III, “An Update of the Angiosperm Phylogeny Group Classification for the Orders and Families of flowering plants: APG III," Botanical Journal of the Linnean Society, Vol. 161, No. 2, 2009, pp. 105-121. doi:10.1111/j.1095-8339.2009.00996.x

[44] M. T. A. Garcia, B. G. Galati and O. S. Hoc, "Ultrastructure of the Corona of Scented and Scentless Flowers of Passiflora spp. (Passifloraceae)," Flora, Vol. 202, No. 4, 2007, pp. 302-315. doi:10.1016/j.flora.2006.08.003

[45] D. Tholl, C. M. Kish, I. Orlova, et al., "Formation of Monoterpenes in Antirrhinum majus and Clarkia breweri Flowers Involves Heterodimeric Geranyl Diphosphate Synthases," The Plant Cell, Vol. 16, No. 4, 2004, pp. 977992. doi: $10.1105 /$ tpc. 020156

[46] L. S. Adler, "The Ecological Significance of Toxic Nec- tar," Oikos, Vol. 91, No. 3, 2001, pp. 409-420. doi:10.1034/j.1600-0706.2000.910301.x

[47] L. L. Smith, J. Lanza and G. C. Smith, "Amino Acid Concentrations in Extrafloral Nectar of Impatiens sultani Increase after Simulated Herbivory," Ecology, Vol. 71, No. 1, 1990, pp. 107-115. doi:10.2307/1940251

[48] R. A. Dixon and N. L. Paiva, "Stress Induced Phenylpropanoid Metabolism," The Plant Cell, Vol. 7, No. 7, 1995, pp. 1085-1097.

[49] T. M. Kutchan, "A Role for Intra- and Intercellular Translocation in Natural Product Biosynthesis," Current Opinion in Plant Biology, Vol. 8, No. 3, 2005, pp. 292-300. doi:10.1016/j.pbi.2005.03.009

[50] M. Otani, N. Shitan, K. Sakai, E. Martinoia, F. Sato and K. Yazaki, "Characterization of Vacuolar Transport of the Endogenous Alkaloid Berberine in Coptis japonica," Plant Physiology, Vol. 138, 2005, pp. 1939-1946. doi:10.1104/pp.105.064352

[51] D. Treutter, "Significance of Flavonoids in Plant Resistance: A Review," Environmental Chemistry Letters, Vol. 4, No. 4, 2006, pp. 147-157. doi:10.1007/s10311-006-0068-8 